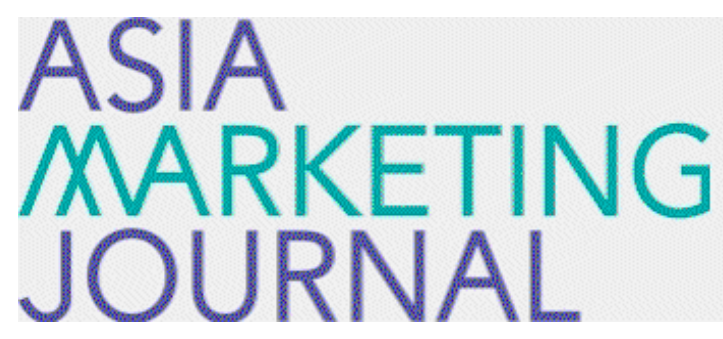

ASIA MARKETING JOURNAL

Volume 16 | Issue 2

Article 3

7-30-2014

\title{
The Influence of the Relationship between Consumer and Tie-in Promotion on Loyalty
}

Eun Mi Lee

Hyun Hee Park

Jung Ok Jeon

Follow this and additional works at: https://amj.kma.re.kr/journal

Part of the Marketing Commons

\section{Recommended Citation}

Lee, Eun Mi; Park, Hyun Hee; and Jeon, Jung Ok (2014) "The Influence of the Relationship between Consumer and Tie-in Promotion on Loyalty," Asia Marketing Journal: Vol. 16 : Iss. 2 , Article 3.

Available at: https://doi.org/10.53728/2765-6500.1539

This Article is brought to you for free and open access by Asia Marketing Journal. It has been accepted for inclusion in Asia Marketing Journal by an authorized editor of Asia Marketing Journal. 


\title{
The Influence of the Relationship between Consumer and Tie-in Promotion on Loyalty: Focusing on the Difference between Target Customers and Non-target Customers of Tie-in Promotion*
}

\author{
Eun Mi Lee** \\ Hyun Hee Park \\ Jung Ok Jeon****
}

There has been recognition of the increasing importance of cooperation as an element of marketing strategy. Such cooperation is confined to four levels based on product development, sales promotion, pricing arrangements, and place (or distribution) mechanisms as the usual marketing 4Ps mixed (Varadarajan 1986). At present, however, little is known about the nature of tie-in promotion as a cooperative sales promotion comparing three other levels.

The primary goal of this study is to examine the effect of consumer - tie-in promotion relationship on loyalty. The construct of consumer - tie-in promotion relationship is based on the previous research on consumer-brand relationship. In addition, this study divides the concept of loyalty into host brand loyalty and partner brand loyalty to reflect the characteristics of tie-in promotion including program in order to determine the effect of the consumer - tie-in promotion relationship on loyalty.

The results showed that the three dimensions of the consumer - tie-in promotion relationship (i.e., commitment, intimacy, and interdependence) had significantly positive effect on program loyalty. The effect of program loyalty is significantly on both host and partner brand loyalty. This study empirically tested the relationships among consumer - tie-in promotion relationship, program loyalty, host brand loyalty, and partner brand loyalty, and then compared with the difference in the suggested model for the target customers and non-target customers. As a result, for target customers, intimacy and interdependence among dimensions of consumer - tie-in promotion relationship had significantly positive influence on program loyalty. In case of non-target customers, however, commitment and

\footnotetext{
* The work was supported by 2014 College of Business Administration Research Fund in Pukyong National University.

** Lecturer, College of Business Administration, Pukyong National University(eunmlee@umich.edu)

*** BK21 Plus Research Professor, School of Business Administration, Kyungpook National University (c21ircle@ hanmail.net)

**** Professor, College of Business Administration, Pukyong National University(jojeon@pknu.ac.kr), Corresponding Author
} 
interdependence among dimensions of consumer - tie-in promotion relationship had significantly positive influence on program loyalty. Also, program loyalty had significantly positive impact on host brand loyalty and partner brand loyalty in both target and non-target customers.

This study has significance in that it addresses the need to identify research and academic implications by analyzing the consumer - tie-in promotion relationship to determine the relationship between tie-in promotion and loyalty, which has not been clearly described by previous studies. Furthermore, this study builds a foundation for firms and managers actively using tie-in promotion to establish tie-in promotion strategies that can maximize loyalty for both host and partner brands from the consumers' point of view.

Key words: Tie-in promotion, Consumer - tie-in promotion relationship, Program loyalty, Host brand loyalty, Partner brand loyalty

\section{Introduction}

Recently, along with the reduction of the advertising effect due to individuation and diversification of consumers, advertising's share of marketing budgets tends to be decreasing. In the meantime, the increase in sales promotion expenses of firms, development of sales promotion media, and increase in the availability of consumer data facilitate promotional activities. Thus, sales promotion has recently become a marketing tool that receives the most attention as an element that directly and quickly influences corporate performance and communication with consumers, rather than merely assisting other marketing activities. Accordingly, firms are increasing their investment in sales promotion and making use of various sales promotion tools; it is not too much to say that we are living in a whirlwind of similar yet diverse sales promotion messages.

In this context, there is an increasing need for alternatives to reduce the negative perception of sales promotion. This perception argues that sales promotion only has influence over short-term performance. In other words, firms intend to achieve the short-term sales goal of generating immediate sales by changing the price-value correlation for consumers through promotion, while at the same time they aim to achieve their long-term communication goals by enhancing their brand value. From a strategic point of view, an intercompany alliance today has significance as a primary means for firms to subsist and prosper, rather than as a complementary and strategic means for shortterm profits. Kanter (1994) argued that an organization chooses to establish an alliance in order to fight against smart competitors, while 
Tully (1993) conducted an empirical study to prove that firms depending on a strategic alliance tend to have higher profitability than do firms employing vertical integration. In these circumstances, firms began to implement and spread tie-in promotion as a new alternative that incorporates an innovative form of promotion. Tie-in promotion can be defined as a strategic tie formed between two different companies to seek common profits from sales increase and profit rate improvement, targeting similar target customers and sharing their promotional resources. Co-branding is a relatively long-term and general strategy marketers use in attempting to transfer the positive associations of the partner (constituent) brands to a newly formed co-brand (composite brand) (Washburn, Till and Priluck 2000). Compared to co-branding strategy, tie-in promotion is distinguished and characterized as timely, limited appearance of two independent brands in promotional activities (Helmig, Huber and Leeflang 2008). As the concept of an intercompany sales promotion alliance was implemented using credit cards for telecommunication companies, the concept of affiliate cards was created as a product of a tie-in promotion strategy. As the partner company shares the marketing costs with the affiliate card company, both can provide greater benefits for consumers, such as discounts or point accumulation. As a result, they can increase current customers' satisfaction level, maximize loyalty through revisits and a pos- itive word-of-mouth effect, increase consumers' brand converting costs, and maintain good relationships with current customers. In particular, a tie-in discount is the greatest benefit and consumer incentive boosted by affiliate cards. This is differentiated from other general price discount promotion programs in that the discount benefits are not provided unconditionally to all customers. Previous studies on tie-in discounts argued that consumers pursuing tiein discounts are price sensitive and influenced by utilitarian motives. In fact, Kim (2003) showed that $40 \%$ of consumers give up on a purchase if they are not using an affiliate card that can secure discount benefits in purchasing a specific brand. Moreover, customers with affiliate cards (target customers) showed higher customer loyalty and satisfaction than did customers without affiliate cards (non-target customers) (Shin and Cha 2011). Research on the repurchase effect of affiliate cards suggested that co-branded cards have a positive influence on improving loyalty, aside from the direct reward of discount benefits (Lee and Choi 2005).

As described above, most studies on tie-in promotion mention the positive effects of tie-in promotion on repurchase intention and loyalty; however, specific research on clarifying the relationship between tie-in promotion and loyalty is insufficient.

Therefore, the key objectives of this study are as follows. First, this study identifies variables related to the consumer - tie-in promotion 
relationship that can be formed by tie-in promotion. Second, to determine the effect of the consumer - tie-in promotion relationship on loyalty, this study divides the concept of loyalty into host brand loyalty and partner brand loyalty to reflect the characteristics of tie-in promotion. Program loyalty is implemented as a parameter in the consumer - tie-in promotion relationship and host and partner brand loyalty relationship to determine the process of loyalty formation more specifically. Third, this study conducts exploratory research on the difference between target customer and non-target customers as a propositional research model in terms of the effect of the consumer - tie-in promotion relationship on program loyalty.

Therefore, this study has significance in that it addresses the need to identify research and academic implications by analyzing the consumer - tie-in promotion relationship to determine the relationship between tie-in promotion and loyalty, which has not been clearly described by previous studies. Furthermore, this study will build a foundation for firms and managers actively using tie-in promotion to establish tie-in promotion strategies that can maximize loyalty for both host and partner brands from the consumers' point of view.

\section{Literature Review and Hypotheses}

\subsection{Concept and effect of tie-in promotion}

The simultaneous promotion of multiple brands from the same or different companies in a single promotional effort is referred to as a tie-in, joint, or cooperative, promotion (Shimp and Andrews 2013). While the classification of $\mathrm{co}^{-}$ operative promotion along inter/intra-company cooperative promotion is widely accepted in the literature (Abbott 1980), Farris and Quelch (1983) classified cooperative promotion into internal horizontal, external horizontal, and $\mathrm{ex}^{-}$ ternal vertical cooperative promotion. Also, Varadarajan (1986) considered five dimensions as the standard of classification for cooperative sales promotion: intercompany/intra-company tie-in, tie-in between same/different product lines, tie-in between single/multiple brand(s), connection with related industry cooperatives, and correlation with charity fund-raising. $\mathrm{He}$ studied opportunities for growth, goals, distinctive benefits, credible issues, and risks, which are factors that need to be considered in planning joint sales promotion between brands of different intercompany product lines.

There are largely three characteristics of the role tie-in promotion plays in firms. First, in terms of products, firms can easily develop 
new markets and secure new customers to sell new products and alternative goods by simultaneously carrying out promotion for each industry or theme and producing a linkage effect between products. Second, in terms of distribution, firms can open a joint store with a small budget while providing economic incentives for consumers and middle merchants. Firms can also increase sales by setting up point-of-purchase (POP) displays or joint exhibitions that were not easy to set up as a single company. Third, in terms of promotion, firms can increase sales promotion in similar or related industries, and expect an advertising amplification effect with more advertising exposure opportunities due to division of advertising expenses (Song 2003).

It can be expected that various tools of tie-in promotion commonly involve beneficial characteristics provided by sales promotion in that the previous sales promotion tools are linked to the partner brand (or company). As Chandon et al. (2000) found, tie-in promotion provides three utilitarian benefits (i.e., saving, quality, and convenience benefits) and three hedonic benefits (i.e., value expression, information, entertainment benefits) to the customers. Moreover, in terms of symbolic alliance strategy, tie-in promotion conveys added significance to consumers by transferring the assets or association of the partner brand to the host brand (James 2006). The image transfer effect due to a symbolic alliance is created in three ways.
First, consumers' emotions and evaluation concerning the previous brand before alliance or extension influence the evaluation of the outcome of an alliance such as jointly branded products or extended products. On the other hand, consumer evaluations after alliance and extension also influence the evaluation on each brand individually (Simonin and Ruth 1998). This spillover effect is also shown between products under umbrella branding, regarding which Sullivan (1990) and Erdem and Sun (2002) stated that it is also influenced by an advertising or sales promotion program.

When comparing the benefits of sales promotion and tie-in promotion in this aspect, tie-in promotion is carried out with a relatively longterm view, unlike sales promotion, which is intended to increase short-term sales. Thus, tiein promotion is a strategy that maximizes additional benefits perceived by consumers as compensating or minimizing the defects and issues of short-term strategies.

\subsection{Consumer-brand relationship vs consumer - tie-in promotion relationship}

Beyond the level of mere consumption of products, consumers have now become active agents that feel human emotions and form various personal relationships with brands through the process of purchasing and using those brands, just as they form relationships with 
other people. As the consumer-brand relationship becomes intimate, it has become important to understand the relationship between the two. This relationship must be established in the long-term view in order to enhance the brand value of companies, especially given that the ultimate goal for a brand asset is to build a good consumer-brand relationship (Keller 1993).

After the research on the relationship between humans and their possessions (Belk 1988), the consumer-brand relationship was first studied in earnest by Blackston (1993), who saw it as a relationship similar to the one between two people as the two parties interact with each other and, consequently, influence each other. Research on the topic was pursued further, emphasizing that the relationship between the two is qualitatively more important based on relational theory (Roberts, Varki, and Brodie 2003; Fournier 1998). This consumer-brand relationship stemmed from the view of personifying brands and perceiving them as members of the relationship. The relationship between the two is a solidarity created by interaction between the two equal parties, consumer and brand, as partners (Kim 2002). Therefore, in a consumer-brand relationship, consumers are so satisfied with the brand's performance or service that they perceive it as something more than just a product to repurchase, and build a relationship with the brand in daily life as they do with human relations.

Consumer-brand relationship indicates that the two parties interact with each other in the long-term view and, consequently, influence each other. Blackston (1991) defined consumer-brand relationship as a compound of cognitive, affective, and behavioral processes that occur between consumer and brand. Accordingly, this study set up the consumer-promotion relationship as a compound of cognitive, affective, and behavioral processes that occur between consumer and tie-in promotion based on the consumer-brand relationship presented in previous studies. As shown in Table 1, since the performing roles of brand and promotion are quite similar, this study attempted to establish new consumer-promotion relationship.

This study aims to present the consumerpromotion relationship as a concept in which

$\langle$ Table 1〉 Role comparison between brand and tie-in promotion

\begin{tabular}{|c|c|c|c|}
\hline & Brand & vs & Tie-in promotion \\
\hline \multirow{3}{*}{$\begin{array}{c}\text { Role } \\
\text { Comparison }\end{array}$} & $\begin{array}{l}\text { Role to represent the product } \\
\text { or company }\end{array}$ & & $\begin{array}{l}\text { Role to recognize the product or } \\
\text { company through promoting sales }\end{array}$ \\
\hline & Role to guarantee the product & & $\begin{array}{l}\text { Role to increase positive evaluation } \\
\text { of host brand utilizing partner brand }\end{array}$ \\
\hline & $\begin{array}{l}\text { Role to create and maintain } \\
\text { customers }\end{array}$ & & Role to create and maintain customers \\
\hline
\end{tabular}


the previous theory on the consumer-brand relationship is applied to the consumer - tie-in promotion relationship.

\subsection{Consumer - tie-in promotion relationship and tie-in program loyalty}

"Loyalty to the loyalty program" refers to how actively members participate in the loyalty program, and how strong their attachment is to the program compared to their attachment to other similar loyalty programs. That is, it is the loyalty to the loyalty program itself such as Happy Point and OK Cashbag. Dowling and Uncle (1997) argue that a customer's awareness of value in the loyalty program does not directly lead to brand loyalty, especially if the product is low-involvement. For low-involvement products, customers tend to purchase the loyalty program because they like the program rather than the product or service, once they feel the value of the program. Yi and Jeon (2003) extend the previous study of Dowling and Uncles (1997) by specifying the scheme of the loyalty program as well as expanding the concept of loyalty. They examine the mediating role of program loyalty in the relationships between value perception of the loyalty program, customer loyalty, and brand loyalty, which depending on involvement.

Therefore, it is necessary to deal with customer loyalty formation through a loyalty pro- gram by separating program loyalty from company/brand loyalty. In particular, when studying a tie-in loyalty program in which networks are formed by sharing the loyalty program, it would be appropriate to distinguish program loyalty from the company/brand loyalty that hosts the loyalty program. This study also examines the mechanism of loyalty formation by separating program loyalty from company/ brand loyalty.

Hypothesis 1: Consumer - tie-in promotion relationship will have an impact on program loyalty.

\subsection{Tie-in program loyalty vs host and partner brand loyalty}

Brand loyalty is defined as a state of deep immersion to repurchase preferred products or services or to become a regular customer, and a tendency to repurchase the same brand despite a marketing strategy aiming for brand switch. Aaker (1991) defined brand loyalty as the core element of brand asset. The study built a pyramid of different stages of brand loyalty and stated that there are different marketing opportunities and different asset types to manage in each stage.

Moreover, a study on measurement and management of brand loyalty defined brand loyalty as the tendency to prefer a certain brand over other brands. Views of the research on loyalty can be divided into behavioral and 
attitudinal views through a theoretical study. In the behavioral view, loyalty is defined as a consumer behavior expressed on the outside. With this standpoint, loyalty is often measured by purchase ratio, purchase sequence, purchase probability, etc. However, the actual cause for repeated buying behavior is unknown when measuring loyalty with behavior. Moreover, as consumers can repeatedly purchase certain products due to convenience, price, availability, and accessibility, it is difficult to adequately explain brand loyalty based on behavior alone.

On the other hand, the attitudinal view makes note of the fact that loyalty cannot be explained only with behavior; it thus points out consumer attachment and preference for brands as key factors. In other words, a mere repetition of behavior cannot explain loyalty. Regarding this, it is measured by brand (and/or name) preference, preference invariability, etc.

Hypothesis 2: Program loyalty will have an impact on host brand loyalty and partner brand loyalty.

\section{Methodology}

\subsection{Brand selection and subject of experiment}

To select brands suitable for the subject of this experiment, a pre-test was conducted at universities in Busan and Daegu, targeting university students taking marketing-related courses. As a result, TNGT and BC Card were selected as brands that were most commonly used by university students and have many tie-in promotion cases.

TNGT is the only suit brand that offers suits for both men and women; thus, it is the most appropriate brand for this experiment targeting male and female university students. Also, BC Card ranked No. 1 in brand power among credit cards for 12 consecutive years issued by Korea Customer Satisfaction Index (KCSI). With these brands, this study examines the population of university students interested in fashion and credit cards, and who have experience in purchasing these products. Samples were extracted from this population.

Furthermore, groups were divided into target customers and non-target customers for tie-in promotion conducted in this study; prospective graduates of university were manipulated as target customers, while undergraduate students excluding prospective graduates were manipulated as non-target customers. In our scenario, target customers were manipulated by the context that this tie-in promotion is limited to senior students who will graduate sooner or later. Basically, the promotion program asked them to bring their ID card which appears an affiliation and years. After reading the scenario, respondents were asked to answer the ques- 
tion "Are you a subject to use this tie-in promotion?" with "Yes/No".

\subsection{Procedure and measurement}

The questionnaires, which consisted of three steps, were distributed. First, as a pre-exposure measure, participants were asked to answer the questions about prior brand attitude and purchase experience of each brand before they watched advertisement stimuli. Second, after they were exposed to the scenario and print advertisement developed for the experimental stimuli, pre-exposure experience of advertisement stimuli, school year, and knowledge of characteristics of tie-in promotion were measured for manipulation check. Third, as a postexposure measure, program loyalty, host brand loyalty, partner brand loyalty, consumer - tiein promotion relationship, product involvement, and demographic characteristics were measured. Among 276 participants, a total number of 227 usable questionnaires were obtained for the analysis.

Consumer - tie-in promotion relationship was measured using 21 items developed and adapted from multidimensional characteristics of the relationship (i.e., love and passion, selfconnection, interdependence, commitment, intimacy, partner brand quality). The items for consumer - tie-in promotion relationship included "I'm attracted to the promotion," "I feel good when I use the promotion," "I feel more special from the promotion than any other promotions."

Loyalty in this study is defined as having high relative attitude or the degree of attachment toward the tie-in loyalty program or brand. For measures of host brand loyalty and partner brand loyalty, three items were used: "I have strong preference for the host (partner) brand," "I would continue to purchase host (partner) brand," "I would recommend the host (partner) brand."

All items for consumer - tie-in promotion relationship and loyalty (i.e., program, host and partner brand) were measured on five-point Likert scales anchored as strongly disagree /strongly agree.

\subsection{Results}

\subsubsection{Exploratory factor analysis}

As preliminary analyses, exploratory factor analysis with Varimax rotation was utilized to check the convergent and discriminant validity of the measurement items. All scores of factor loading were greater than 0.510 , indicating a stable loading structure (Table 2).

As shown in Table 2, consumer - tie-in promotion relationship had a three factor solutions, altogether explaining $71.69 \%$ of total variance. These three factors were named based on the items that loaded the highest for each factor. Factor 1 had three statements and 
accounted for $36.52 \%$ of the variance and this factor was labeled as commitment. Factor 2 had three statements and accounted for $8.77 \%$ of the variance and labeled as intimacy. Factor 3 had three statements and accounted for $5.78 \%$ of the variance and labeled as interdependence. Loyalty toward tie-in promotion had three statements and accounted for 6.92\%, loyalty toward own brand had three statements and accounted for $6.23 \%$, loyalty toward partner brand had three statements and accounted for $5.64 \%$.
Cronbach's alpha scores were calculated for each construct to show internal consistency. As shown in Table 2, the Cronbach's alpha values ranged from 0.744 to 0.833 . The Cronbach's alpha values above 0.70 are considered as acceptable (Nunnally 1978). Therefore, all values showed that internal consistency reliability of each construct was deemed appropriate. And then the validity of the measurement items was re-tested through confirmatory factor analysis.

〈Table 2〉 Exploratory factor analysis and reliability analysis

\begin{tabular}{|c|c|c|c|c|c|c|c|c|c|c|c|}
\hline & \multicolumn{2}{|c|}{ Items } & Factor 1 & Factor 2 & Factor 3 & Factor 4 & Factor 5 & Factor 6 & Eigen & $\begin{array}{l}\text { Variance } \\
(7169)\end{array}$ & Cron- \\
\hline \multirow{10}{*}{$\begin{array}{l}\text { Consumer - } \\
\text { tie-in } \\
\text { promotion } \\
\text { relationship }\end{array}$} & \multirow{3}{*}{$\begin{array}{c}\text { Commit- } \\
\text { ment }\end{array}$} & $\mathrm{X} 1$ & .866 & .199 & .165 & .058 & .152 & .145 & \multirow{3}{*}{6.94} & \multirow{3}{*}{36.52} & \multirow{3}{*}{0.811} \\
\hline & & $\mathrm{X} 2$ & .835 & .203 & .240 & .090 & .091 & .158 & & & \\
\hline & & X3 & .648 & .094 & .000 & .153 & .207 & .184 & & & \\
\hline & \multirow{4}{*}{ Intimacy } & $\mathrm{X} 4$ & .172 & .845 & .028 & .160 & .039 & -.046 & \multirow{4}{*}{1.67} & \multirow{4}{*}{8.77} & \multirow{4}{*}{0.786} \\
\hline & & X5 & .121 & .787 & .141 & .090 & .038 & .221 & & & \\
\hline & & $\mathrm{X} 6$ & .095 & .678 & .202 & .003 & .257 & .191 & & & \\
\hline & & $\mathrm{X} 7$ & .357 & .510 & .111 & .262 & .205 & .183 & & & \\
\hline & \multirow{3}{*}{$\begin{array}{l}\text { Interde- } \\
\text { pendence }\end{array}$} & $\mathrm{X} 8$ & .085 & .151 & .825 & .039 & .073 & .082 & \multirow{3}{*}{1.44} & \multirow{3}{*}{5.78} & \multirow{3}{*}{0.744} \\
\hline & & X9 & .186 & .073 & .765 & .191 & .104 & .136 & & & \\
\hline & & $\mathrm{X} 10$ & .331 & .192 & .620 & .197 & .181 & .132 & & & \\
\hline \multirow{3}{*}{\multicolumn{2}{|c|}{ Program loyalty }} & Y1 & .101 & .075 & .050 & .839 & .033 & .018 & \multirow{3}{*}{1.32} & \multirow{3}{*}{6.92} & \multirow{3}{*}{0.814} \\
\hline & & $\mathrm{Y} 2$ & .113 & .182 & .196 & .803 & .207 & .165 & & & \\
\hline & & Y3 & .106 & .109 & .162 & .737 & .163 & .322 & & & \\
\hline \multirow{3}{*}{\multicolumn{2}{|c|}{ Host brand loyalty }} & Y4 & .095 & .098 & .104 & .038 & .829 & .142 & \multirow{3}{*}{1.89} & \multirow{3}{*}{6.23} & \multirow{3}{*}{0.797} \\
\hline & & Y5 & .265 & .170 & .088 & .106 & .774 & .143 & & & \\
\hline & & $\mathrm{Y} 6$ & .134 & .099 & .138 & .315 & .708 & .242 & & & \\
\hline \multirow{3}{*}{\multicolumn{2}{|c|}{ Partner brand loyalty }} & $\mathrm{Y7}$ & .151 & .138 & .095 & .066 & .121 & .842 & \multirow{3}{*}{1.07} & \multirow{3}{*}{5.64} & \multirow{3}{*}{0.833} \\
\hline & & Y8 & .051 & .142 & .105 & .208 & .117 & .817 & & & \\
\hline & & Y9 & .210 & .101 & .149 & .163 & .328 & .735 & & & \\
\hline
\end{tabular}




\subsubsection{Confirmatory factor analysis}

The measurement scales and fit statistics are shown in Table 3. All values exceeded the recommended level: $\chi^{2}=193.47$, d.f. $=104, \chi^{2} /$ d.f. $=1.860, \quad \mathrm{RMR}=0.046, \mathrm{GFI}=0.914$, AGFI $=$ 0.873, TLI $=0.932, \quad \mathrm{CFI}=0.948$ (Hair et al., 1995). These statistics suggest that the data reasonably fit the model. The results also show that each factor was a unidimensional construct.

The convergent validity of variables was assessed based on the factor loadings, composite reliabilities (CR), and average variances $\mathrm{ex}^{-}$ tracted (AVE). As shown in Table 3, the factor loadings of all items exceeded the recommended level of 0.50 after removing two items. And all $t$-values corresponding to the paths between the scales and their respective factors were significant at 0.001 . The $\mathrm{CR}$, which depicts the degree to which the construct indicators indicate the latent construct, exceeded the recommended level of 0.70. The AVE, which reflects the overall amount of variance in the indicators accounted for by the latent construct, exceeded the recommended level of 0.50. All these figures show that the con-

〈Table 3〉 The result of confirmatory factor analysis for measures

\begin{tabular}{|c|c|c|c|c|c|c|}
\hline Variables & $\begin{array}{c}\text { Stand. Factor } \\
\text { loading }\end{array}$ & $\begin{array}{c}\text { Measurement } \\
\text { error }\end{array}$ & $\begin{array}{c}\text { Items } \\
\text { Before CFA }\end{array}$ & $\begin{array}{c}\text { Items } \\
\text { After CFA }\end{array}$ & $\mathrm{CR}$ & AVE \\
\hline \multirow{3}{*}{ Commitment } & 0.529 & 0.865 & \multirow{3}{*}{3} & \multirow{3}{*}{3} & \multirow{3}{*}{0.739} & \multirow{3}{*}{0.623} \\
\hline & 0.917 & 0.160 & & & & \\
\hline & 0.914 & 0.158 & & & & \\
\hline \multirow{3}{*}{ Intimacy } & 0.597 & 0.546 & \multirow{3}{*}{4} & \multirow{3}{*}{3} & \multirow{3}{*}{0.750} & \multirow{3}{*}{0.502} \\
\hline & 0.737 & 0.433 & & & & \\
\hline & 0.694 & 0.386 & & & & \\
\hline \multirow{3}{*}{ Interdependence } & 0.784 & 0.389 & \multirow{3}{*}{3} & \multirow{3}{*}{3} & \multirow{3}{*}{0.750} & \multirow{3}{*}{0.502} \\
\hline & 0.687 & 0.415 & & & & \\
\hline & 0.627 & 0.660 & & & & \\
\hline \multirow{2}{*}{ Program loyalty } & 0.816 & 0.325 & \multirow{2}{*}{3} & \multirow{2}{*}{2} & \multirow{2}{*}{0.821} & \multirow{2}{*}{0.695} \\
\hline & 0.836 & 0.272 & & & & \\
\hline \multirow{3}{*}{$\begin{array}{c}\text { Host brand } \\
\text { loyalty }\end{array}$} & 0.779 & 0.234 & \multirow{3}{*}{3} & \multirow{3}{*}{3} & \multirow{3}{*}{0.851} & \multirow{3}{*}{0.655} \\
\hline & 0.696 & 0.376 & & & & \\
\hline & 0.783 & 0.285 & & & & \\
\hline \multirow{3}{*}{$\begin{array}{c}\text { Partner brand } \\
\text { loyalty }\end{array}$} & 0.753 & 0.403 & \multirow{3}{*}{3} & \multirow{3}{*}{3} & \multirow{3}{*}{0.848} & \multirow{3}{*}{0.652} \\
\hline & 0.776 & 0.332 & & & & \\
\hline & 0.833 & 0.259 & & & & \\
\hline Fit: $\chi^{2}=$ & 47 , d.f. $=104$ & $=0.914, \mathrm{AGFI}$ & 0.873, TLI $=0$ & $32, \mathrm{CFI}=0.9$ & $\mathrm{MR}=$ & \\
\hline
\end{tabular}


vergent validity of variables is convincing.

A construct should share more variance within its measures, than it shares with other constructs in the model (Hair et al. 1995). The average variance extracted should exceed the square of the correlation coefficient of the construct (Fornell and Larcker 1981). None of the squares of correlation coefficients for constructs exceeded the average variance extracted for constructs. Consequently, all constructs $\mathrm{ex}^{-}$ hibited satisfactory discriminant validity. In sum, confirmatory analyses indicated the scales had sound psychometric properties (see Table 4).

\subsubsection{Hypothesis testing}

The overall fit of the structural model was confirmed after assessing its reliability, convergent, and discriminant validity (Hair et al. 1995). The estimated standardized coefficients and their associated $t$-values were examined in testing the hypothesized relationships. First, analysis for all groups was executed. Fit statistics show that almost all values are exceeding the recommended level: $\chi^{2}=281.081$ ( $p$ < $.01), \quad$ d.f. $=206, \quad \chi^{2} /$ d.f. $=1.364, \quad R M R=0.053$, $\mathrm{GFI}=0.917, \quad \mathrm{AGFI}=0.877, \mathrm{TLI}=0.959, \quad \mathrm{CFI}=$ 0.969. Thus, the model was found acceptable and the proposed hypotheses were tested.

Hypothesis 1 was predicted that the consumer - tie-in promotion relationship would affect program loyalty. As a result of analysis, the three dimension of the consumer - tie-in promotion relationship (commitment, intimacy, interdependence) had significantly positive effect on program loyalty. Therefore, Hypothesis 1 was supported.

Hypothesis 2 was predicted that program loyalty would influence host brand loyalty and partner brand loyalty. As a result of analysis, program loyalty had significantly positive impact on partner brand loyalty as well as host brand loyalty (see Figure 1). Thus, Hypothesis 2 was supported.

$\langle$ Table 4〉 The squared correlations and AVE of the constructs

\begin{tabular}{|c|c|c|c|c|c|c|}
\hline & $\begin{array}{c}\text { Commitment } \\
(1)\end{array}$ & $\begin{array}{c}\text { Intimacy } \\
(2)\end{array}$ & $\begin{array}{c}\text { Interdependence } \\
(3)\end{array}$ & $\begin{array}{c}\text { Program loyalty } \\
(4)\end{array}$ & $\begin{array}{c}\text { Host brand loyalty } \\
(5)\end{array}$ & $\begin{array}{c}\text { Partner brand } \\
\text { Loyalty } \\
(6)\end{array}$ \\
\hline$(1)$ & 0.623 & & & & & \\
\hline$(2)$ & 0.369 & 0.502 & & & & \\
\hline$(3)$ & 0.332 & 0.447 & 0.502 & & & \\
\hline$(4)$ & 0.152 & 0.287 & 0.337 & 0.695 & & \\
\hline$(5)$ & 0.253 & 0.355 & 0.285 & 0.341 & 0.655 & 0.652 \\
\hline$(6)$ & 0.230 & 0.316 & 0.255 & 0.344 & 0.385 & \\
\hline
\end{tabular}

※ Bold values in the diagonal are the AVE for each construct and values at lower diagonal cells are the squared correlations among constructs 
〈Figure 1〉 the result of path analysis (all groups)

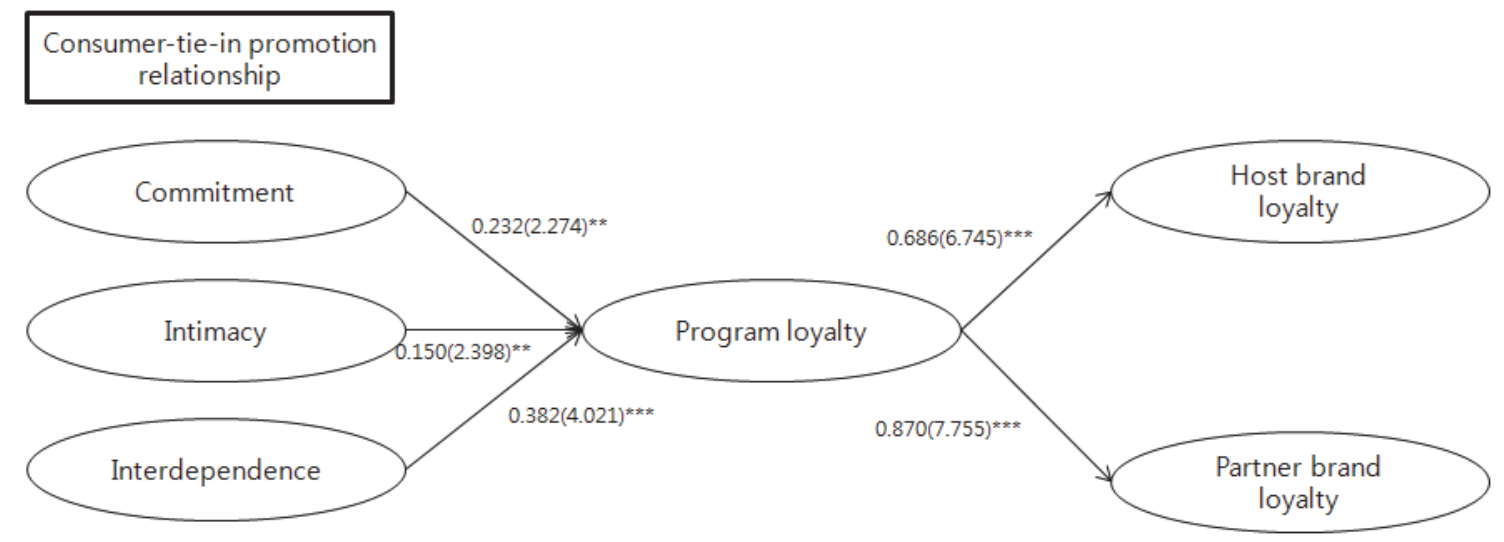

Next, more specifically, path analysis for target customers and non-target customers were executed. In case of target customers, fit statistics show that almost all values are exceeding the recommended level: $\chi^{2}=283.62(p<$ $.01), \quad$ d.f. $=206, \quad \chi^{2} /$ d.f. $=1.376, \quad \mathrm{RMR}=0.057$, $\mathrm{GFI}=0.879, \quad$ AGFI $=0.821, \quad \mathrm{TLI}=0.938, \quad \mathrm{CFI}=$ 0.953. Thus, the model was found acceptable and the proposed hypotheses were tested.

Regarding the hypothesis 1 and 2, intimacy and interdependence among dimensions of consumer - tie-in promotion relationship had significantly positive influence on program loyalty. And, program loyalty had significantly positive impact on host brand loyalty and partner brand loyalty (see Figure 2).

In case of non-target customers, fit statistics show that almost all values are exceeding the recommended level: $\chi^{2}=243.62(p<.01)$, d.f. $=206, \chi^{2} /$ d.f. $=1.182, \mathrm{RMR}=0.058, \mathrm{GFI}=0.898$,

〈Figure 2〉 The result of path analysis (target customers)

Consumer-tie-in promotion relationship

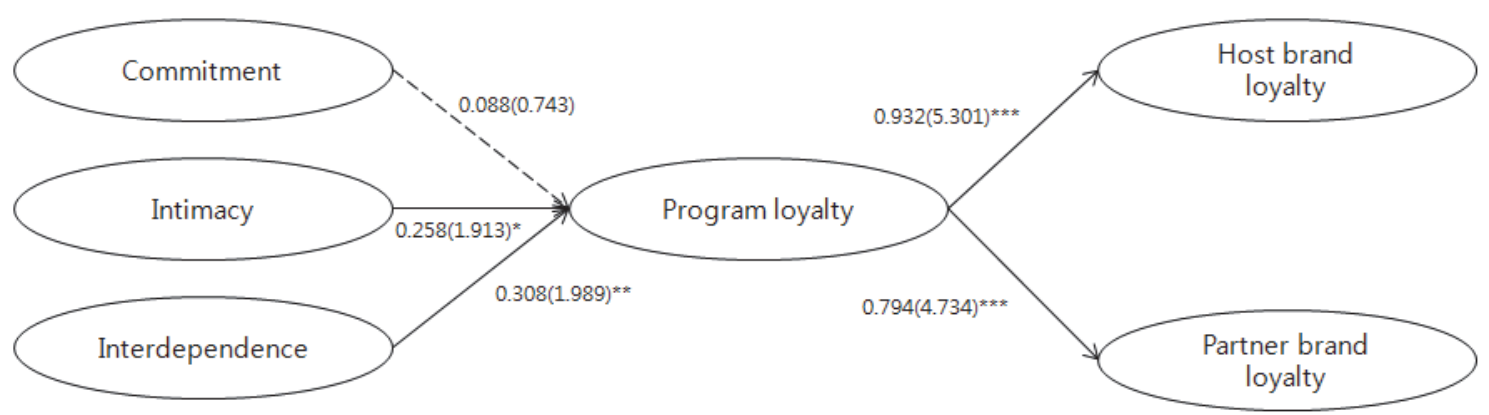

The Influence of the Relationship between Consumer and Tie-in Promotion on Loyalty 51 
AGFI $=0.848$, TLI $=0.964, \quad \mathrm{CFI}=0.972$. Thus, the model was found acceptable and the proposed hypotheses were tested.

Regarding hypothesis 1 and 2, commitment and interdependence among dimensions of consumer - tie-in promotion relationship had significantly positive influence on program loyalty. And, program loyalty had significantly positive impact on host brand loyalty and partner brand loyalty (see Figure 3).

Finally, we identified the difference in the effect of consumer - tie-in promotion relationship on loyalty between target customers and non-target customers. We simultaneously estimate the target customers versus non-target customer cases with suggested models. Figure 4 shows the difference of the structural model between target customers and non-target customers. To evaluate these differences statistically, chi-square difference tests between the two groups were conducted. The full model was compared with the restricted model in- cluding the equality constraints for five paths: commitment $\rightarrow$ program loyalty, intimacy $\rightarrow$ program loyalty, interdependence $\rightarrow$ program loyalty, program loyalty $\rightarrow$ host brand loyalty, and program loyalty $\rightarrow$ partner brand loyalty. According to the results, the restrictions of equal coefficients were rejected in two paths: commitment $\rightarrow$ program loyalty $\left(\Delta \chi^{2}(1)=\right.$ 2.734, $\mathrm{p}<0.1$ ) and program loyalty $\rightarrow$ host brand loyalty $\left(\Delta \chi^{2}(1)=3.205, \mathrm{p}<0.1\right)$. Although the impact of commitment on program loyalty was not significant in target group, the difference in chi-square value was significant $\left(\Delta \chi^{2}(1)=2.734, \mathrm{p}<0.1\right)$. Also, the influence of program loyalty on host brand loyalty was significant in both groups. Moreover, the impact was stronger in target group than non-target group. The results reconfirmed our expectation. However, the restrictions of equal coefficients were accepted in three paths: intimacy $\rightarrow$ program loyalty, interdependence $\rightarrow$ program loyalty, and program loyalty $\rightarrow$ partner

〈Figure 3〉 The result of path analysis (non-target customers)

Consumer-tie-in promotion

relationship

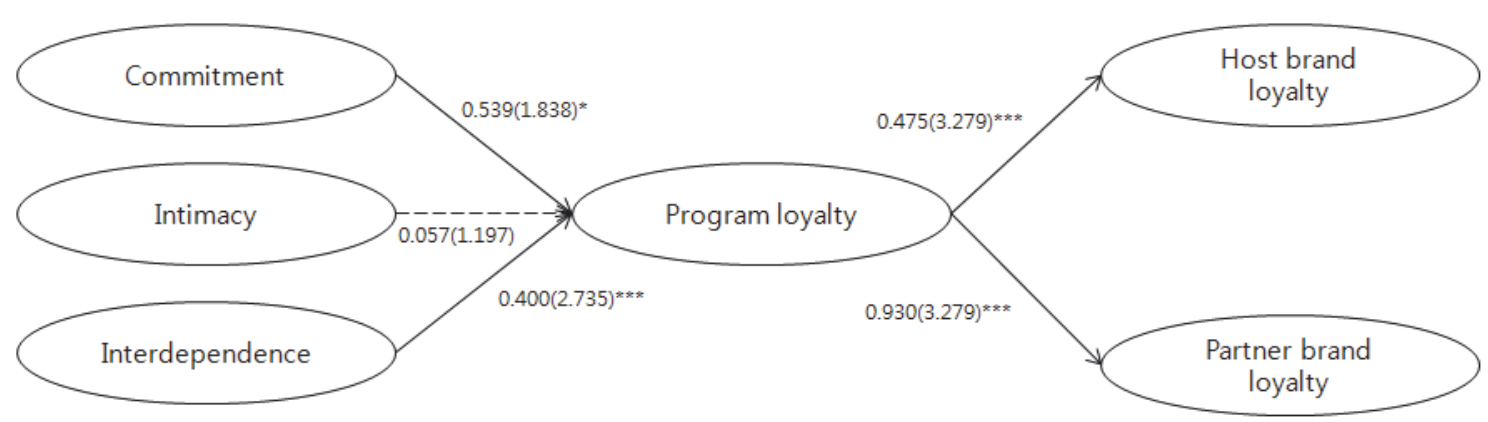


〈Figure 4〉 The result of chi-square test between target customers and non-target customers

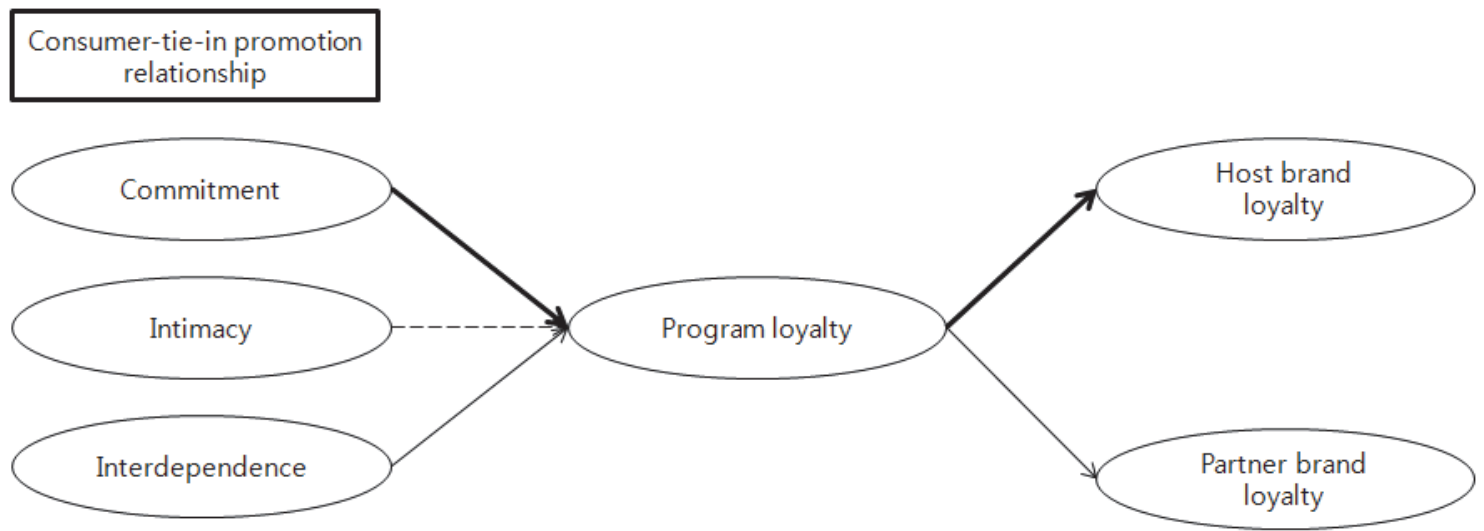

$\longrightarrow$ Significant path in Chi-square difference test

$----\rightarrow$ Insignificant path in Chi-square difference test but significant path in SEM

$\longrightarrow$ Insignificant path in Chi-square difference test and insignificant path in SEM

brand loyalty.

\section{Conclusions and Implications}

Most studies related to tie-in promotion have investigated from the perspective of $\mathrm{co}^{-}$marketing in order to identify the effect of tie-in promotion. However, this study was intended to identify the effect of tie-in promotion from the perspective of consumer and to establish consumer loyalty formation process by the tiein promotion.

Respondents were asked to complete the survey for the consumer - tie-in promotion relationship (commitment, intimacy, interdependence), program loyalty, host brand loyalty, and part- ner brand loyalty with regard to tie-in promotion print ads which have diverse tools. Specifically, this study paid attention to the differences in the effect of consumer - tie-in promotion relationship on loyalty between target customers and non-target customers.

The results of this study are as follows.

First, the three dimension of the consumer tie-in promotion relationship (commitment, intimacy, interdependence) had significantly positive effect on program loyalty. Therefore, hypothesis 1 was supported. Second, the program loyalty had significantly positive impact on host brand loyalty and partner brand loyalty. Thus, hypothesis 2 was supported.

In case of target customers, intimacy and interdependence among dimensions of consumer - tie-in promotion relationship had significantly 
positive influence on program loyalty. Also, program loyalty had significantly positive impact on host brand loyalty and partner brand loyalty.

In case of non-target customers, commitment and interdependence among dimensions of consumer-promotion relationship had significantly positive influence on program loyalty. Also, program loyalty had significantly positive impact on host brand loyalty and partner brand loyalty.

This study empirically tested the relationships among consumer - tie-in promotion relationship, program loyalty, host brand loyalty, and partner brand loyalty, and then compared with the difference in the suggested model for the target customers and non-target customers. As a result, the restrictions of equal coefficients were rejected in two paths: commitment $\rightarrow$ program loyalty and program loyalty $\rightarrow$ host brand loyalty. Although the impact of commitment on program loyalty was not significant in target group, the difference in chi-square value was significant. Also, the influence of program loyalty on host brand loyalty was significant in both groups. Moreover, the impact was stronger in target group than non-target group. However, the restrictions of equal coefficients were accepted in three paths: intimacy $\rightarrow$ program loyalty, interdependence $\rightarrow$ program loyalty, and program loyalty $\rightarrow$ partner brand loyalty.

As a significance of this study, long-term promotion effect was explored through struc- tural model analysis using consumer - tie-in promotion relationship and customer loyalty in the context of tie-in promotion. The dimensions of consumer - tie-in promotion relationship, commitment, intimacy, and interdependence, demonstrated that tie-in promotion was found to be the extended type of sales promotion due to symbolic characteristics of combined brands as well as immediate inducement for consumer's purchase. That is, it implies that the effect of tie-in promotion should be considered importantly in the aspect of corporate image and brand equity.

The difference in the influence of the program loyalty on host and partner brand loyalty was significant according to target group and non-target group. In case of target group, program loyalty had stronger influence on host brand loyalty than partner brand loyalty, while, in case of non-target group, it had stronger influence on partner brand loyalty than host brand loyalty.

One implication of the results is that program loyalty strongly operated host brand since strong brand equity of partner brand transferred to host brand automatically. Therefore, it is expected that target marketing strategy has a greater positive spillover effect than mass marketing strategy which is targeted to random people, by limiting the problems which could happen in the tie-in promotion programs such as decrease of brand preference, decrease of brand awareness and dilution effect of host 
brand due to the strong partner brand power.

The results of this study are practically helpful for the companies which consider tie-in marketing with target market. In Lee et al. (2011)'s study, the fit between tie-in promotion supplying benefit and consumer pursuit benefit, complementation between purchase product and tie-in promotion, alliance with famous partner brand, diverse promotion supply, relevance with purchase product, concept congruency between purchase product and tie-in promotion were suggested as expected benefits of tie-in promotion. In particular, tie-in promotion which is in accord with consumer pursuit benefit promotes consumers' brand purchase, while tie-in promotion which is not in accord with consumer pursuit benefit is easily ignored by consumers. Therefore, marketers should pay attention to the program segmentation strategy based on benefit fit of tie-in promotion considering the traits of host and partner brands.

The limitations and the directions of future studies are as follows.

First, host brand, TNGT, which has selected from the pre-test, showed relatively low level of awareness and preference compared with partner brand, BC Card. When successful image transfer effect is considered, it is common to choose more well-known and familiar brand than own brand as an alliance brand. However, it is needed to control previous level of awareness and preference of host brand and partner brand in order to identify pure effect of tie-in promotion on host brand loyalty. Therefore, for future studies, it is expected to find out the method classifying alliance level according to the level of awareness (or preference) as match/ mismatch or symmetry/asymmetry in order to complement this limitation.

Second, it is predicted that consumer responses toward tie-in promotion will appear more clearly to the consumers with high frequency and spending level of credit card. Therefore, if the research is conducted after segmenting the experimental group according to income level and age group, the study will provide practically more important implications in establishing tie-in promotion strategy.

〈Received March 18. 2014〉

〈Revised July 22. 2014〉

$\langle$ Accepted July 27. 2014〉

\section{References}

Aaker, D. A. (1991), Managing Brand Equity, The Free Press, NY: New York.

Abbott, C. M. (1980), "Two Could Be More Mighty-than Just One in Promotions," Advertising Age, 51 (May 5), S-21, S-23.

Belk, R. W. (1988), "Possessions and the Extended Self," Journal of Consumer Research, 15 (2), 139-168.

Blackston, M. (1991), "Observation: Building Brand Equity by Managing the Brand 
Relationships," Journal of Advertising Research, 32 (2), 79-83.

Blackston, M. (1993), "Beyond Brand Personality: Building, Brand Relationship," in Brand Equity and Advertising: Advertising Role in Building Strong Brands, David A. Aaker and Alexander L. Biel, eds., Lawrence Erlbaum Associates, 113124.

Chandon, P., Brian Wansink and Gilles Laurent (2000), "A Benefit Congruency Framework of Sales Promotion Effectiveness," Journal of Marketing, 64 (4), 65-81.

Dowling, G. R. and M. D. Uncles (1997), "Do Customer Loyalty Programs Really Work," Sloan Management Review, 38 (4), 71-82.

Erdem, T. and B. Sun (2002), "An Empirical Investigation of the Spillover Effects of Advertising and Sales Promotions in Umbrella Branding," Journal of Marketing Research, 39 (4), 1-16.

Farris, P. W. and J. A. Quelch (1983), Advertising and Promotion Management: A Manager's Guide to Theory and Practice, Radner, PA: Chilton.

Fornell, C. and D. F. Larcker (1981), "Structural Equation Models with Unobservable Variables and Measurement Error: Algebra and Statistics," Journal of Marketing Research, 18 (3), 382-388.

Fournier, S. (1998), "Consumers and Their Brands: Developing Relationship Theory in Consumer Research," Journal of Consumer
Research, 24 (4), 343-353.

Hair, J. F. Jr., R. E. Anderson, R. L. Tatham, and W. C. Black (1995), Multivariate Data Analysis With Readings, New Jersey: Prentice-Hall.

Helmig, Bernd, Jan-Alexander Huber, and Peter S. H. Leeflang (2008), Co-Branding: The State of the Art, Schmalenbach Business Review, 60 (October), 359-377.

James, D. O. (2006), "Extension to alliance: Aaker and Keller's model revisited," Journal of Product \& Brand Management, 15 (1), 15-22.

Kanter, R. M. (1994), "Collaborative Advantage: The Art of Alliance," Harvard Business Review, 72 (4), 96-108.

Keller, K. L. (1993), "Conceptualizing, Measuring, and Managing Customer-Based Brand Equity," Journal of Marketing, 57 (1), 1-22. Kim, J. (2003), A Study on the Negative Effects of Alliance Marketing, Master Thesis, Korea University.

Kim, Y (2002), "Dimensions of Consumer-Brand relationships," Advertising Research, 54. 7-32.

Lee, J. and H. Choi (2005), "The Impact of Co-branding Card on Customer Satisfaction in Hotel," Journal of Hospitality and Tourism Studies, 7 (2), 256-275.

Lee, E., H. Park, and J. Jeon (2011), “An Exploratory Study on Tie-in Promotion," Asia Marketing Journal, 13 (1), 27-50.

Nunnally, J. (1978), Psychometric Theory, 
New York: McGraw-Hill.

Roberts, K., S. Varki, and R. Brodie (2003), "Measuring the Quality of Relationships in Consumer Services: An Empirical Study," European Journal of Marketing, 37 (1/2), 169-196.

Shimp, T. A. and J. C. Andrews (2013), Advertising, Promotion, and Other Aspects of Integrated Marketing Communications, 9th ed., Mason, OH: South-Western Cengage Learning, Mason: $\mathrm{OH}$.

Shi, Y. and K. Cha (2011), A Study on the Allianced Discount Program with Credit Cards and Loyalty Cards in Food \& Beverage Industry," Asia Marketing Journal, 12 (4), 55-78.

Simonin, B. L. and J. A. Ruth (1998), "Is The Company Known By The Company It Keeps? Assessing the Spillover Effects Of Brand Alliances on Consumer Brand Attitudes," Journal of Marketing Research, 35 (1), 30-42.
Song, J. (2003), “A Concept Analysis and Comparative Study of Korea and Japan on the Cooperative Advertising," The Korea Journal of Advertising and Public Relation, 5 (1), 95-128.

Sullivan, M. W. (1990), "Measuring Spill-overs in Umbrella Branded Products," Journal of Business, 63 (3), 309-329.

Tully, S. (1993), The Modular Corporation, Fortune, 127, 106-115.

Varadarajan, P. R. (1986), "Cooperative Sales Promotion: An Idea Whose Time Has Come," Journal of Consumer Marketing, 3 (1), 15-33.

Washburn, Judith H., Brian D. Till, and Randi Priluck (2000) "Co-branding: Brand Equity and Trial Effects," Journal of Consumer Marketing, 17 (7), 591-604.

Yi, Y. and H. Jeon (2003), "Effects of Loyalty Programs on Value Perception, Program Loyalty, and Brand Loyalty," Journal of the Academy of Marketing Science, 31 (3), 229-240. 